\title{
Morphologies of spin-coated films of a library of diblock copoly(2-oxazoline)s and their correlation to the corresponding surface energies
}

\author{
Citation for published version (APA): \\ Höppener, S., Wiesbrock, F. D., Hoogenboom, R., Thijs, H. M. L., \& Schubert, U. S. (2006). Morphologies of \\ spin-coated films of a library of diblock copoly(2-oxazoline)s and their correlation to the corresponding surface \\ energies. Macromolecular Rapid Communications, 27(6), 405-411. https://doi.org/10.1002/marc.200500863
}

DOI:

10.1002/marc.200500863

Document status and date:

Published: 01/01/2006

\section{Document Version:}

Publisher's PDF, also known as Version of Record (includes final page, issue and volume numbers)

\section{Please check the document version of this publication:}

- A submitted manuscript is the version of the article upon submission and before peer-review. There can be important differences between the submitted version and the official published version of record. People interested in the research are advised to contact the author for the final version of the publication, or visit the DOI to the publisher's website.

- The final author version and the galley proof are versions of the publication after peer review.

- The final published version features the final layout of the paper including the volume, issue and page numbers.

Link to publication

\footnotetext{
General rights

- You may freely distribute the URL identifying the publication in the public portal. follow below link for the End User Agreement:

www.tue.nl/taverne

\section{Take down policy}

If you believe that this document breaches copyright please contact us at:

openaccess@tue.nl

providing details and we will investigate your claim.
}

Copyright and moral rights for the publications made accessible in the public portal are retained by the authors and/or other copyright owners and it is a condition of accessing publications that users recognise and abide by the legal requirements associated with these rights.

- Users may download and print one copy of any publication from the public portal for the purpose of private study or research.

- You may not further distribute the material or use it for any profit-making activity or commercial gain

If the publication is distributed under the terms of Article $25 \mathrm{fa}$ of the Dutch Copyright Act, indicated by the "Taverne" license above, please 
Summary: The influence of surface morphologies on the properties of materials is of essential importance and is therefore a widely discussed topic. In the present contribution, the properties of a set of diblock copoly(2-oxazoline)s are analyzed in terms of their individual morphologies, which have been investigated with tapping-mode SFM. This collection of diblock copolymers consists of 12 diblock copolymers and four corresponding homopolymers, representing a complete 16-membered library of (co-) poly(2-oxazoline)s, composed of four differently substituted 2-oxazoline monomers. For the investigated set of compounds, a correlation between the morphologies of the spin-coated films and their surface energies could be determined.

Morphologies of spin-coated films of a library of diblock copoly(2-oxazoline)s and their correlation to the corresponding surface energies.
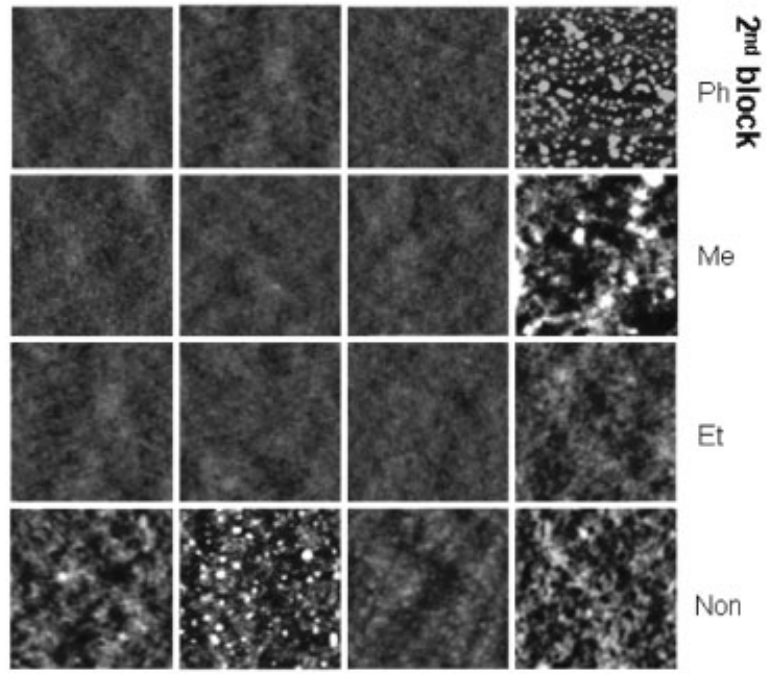

$\mathrm{Me}$

$1^{\text {st }}$ block

Et

$2.5 \mathrm{~nm}$
Non
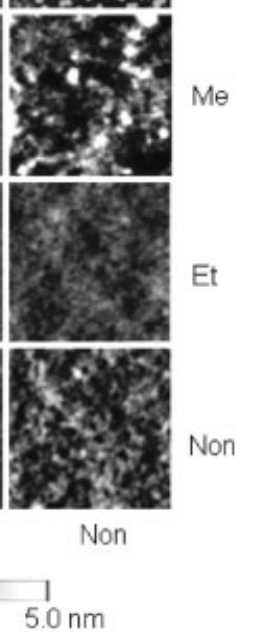

\section{Morphologies of Spin-Coated Films of a Library of Diblock Copoly(2-oxazoline)s and Their Correlation to the Corresponding Surface Energies}

\section{Stephanie Hoeppener, Frank Wiesbrock, Richard Hoogenboom, Hanneke M. L. Thijs, Ulrich S. Schubert*}

Laboratory of Macromolecular Chemistry and Nanoscience, Eindhoven University of Technology and Dutch Polymer Institute (DPI), Den Dolech 2, 5600 MB Eindhoven, The Netherlands

Fax: (+31) 40247 4186; E-mail: u.s.schubert@tue.nl

Received: November 18, 2005; Accepted: January 16, 2006; DOI: 10.1002/marc.200500863

Keywords: diblock copolymers; film morphology; library; material properties; poly(2-oxazoline); scanning force microscopy; surface energy

\section{Introduction}

A large number of differently substituted 2-oxazolines can be prepared from the reaction of nitriles with 2 -aminoethanol. ${ }^{[1,2]}$ These 2-oxazolines are well-suited monomers for the living cationic ring-opening polymerizations (Scheme 1 ), and, for this reason, are under constant investigation since 1966. ${ }^{[3-6]}$ As a consequence of the living character of the polymerization (which means that the growth of all polymer chains starts at the same time and that all polymer chains grow with uniform speed while chain transfer reactions, terminating reactions, as well as other sidereactions are absent), the reaction center (the positively charged oxazolinium ring, Scheme 1) remains active after the complete consumption of the first type of monomer and allows the subsequent incorporation of another type of monomer into the polymer chain. Thus, diblock copoly(2oxazoline)s can be obtained in a two-step procedure and may be applied in fields as diverse as micellar catalysis, drug delivery, or hydrogels. ${ }^{[6-17]}$ 


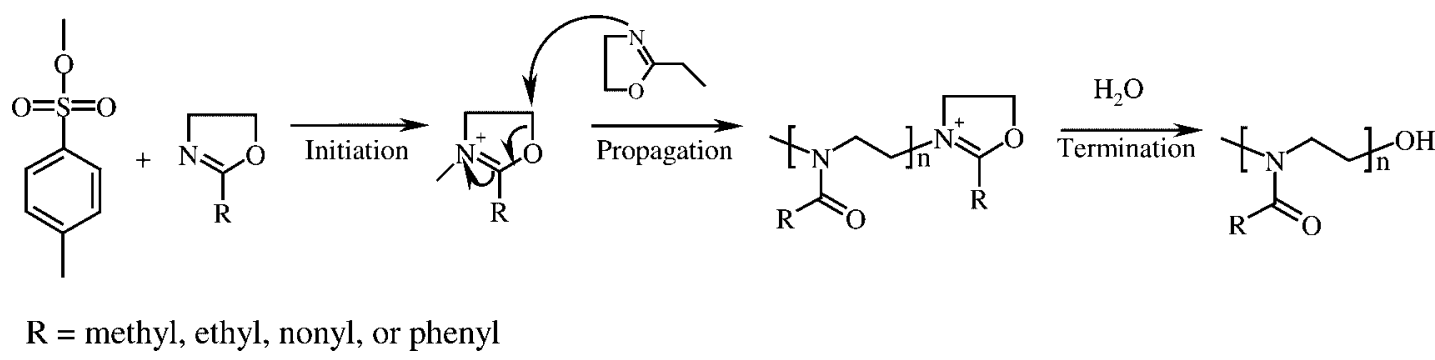

Scheme 1. Schematic presentation of the living cationic ring-opening polymerization of 2-substituted 2-oxazolines initiated by methyl tosylate.

However, the comparably long reaction time for the polymerization of 2-oxazolines has often been a major concern in this research area. Recently, we have shown that the required reaction times could be significantly decreased if the polymerizations were performed in acetonitrile or dichloromethane at increased temperatures (concomitant with higher pressures) in a microwave reactor. ${ }^{[18-20]}$ Nonthermal microwave effects, ${ }^{[21]}$ however, were not observed. Instead, the accelerations originated from the increased temperatures and, consequently, perfectly complied with theoretical calculations that were based on the Arrhenius equation (which also could be proven by reference experiments with conventional heating under pressure). ${ }^{[18,22]}$ Utilizing four differently substituted 2-oxazolines, namely 2-methyl-, 2-ethyl-, 2-nonyl-, and 2-phenyl-2-oxazoline, a 16-membered set of 12 diblock copoly(2-oxazoline)s and 4 chain-extended homopoly(2-oxazoline)s was synthesized under microwave irradiation (Table 1). ${ }^{[23]}$

These compounds showed only slight deviations from the targeted composition of $50+50$ monomer units and exhibited narrow average molecular weight distributions (indicated by PDI values around 1.2; for the two exceptions from this rule, $\mathrm{Non}_{50} \mathrm{Me}_{50}$ and $\mathrm{Non}_{50} \mathrm{Et}_{46}$, see below and ref. $\left.^{[23]}\right)$. The subsequent characterization of this set of poly(2-oxazoline)s revealed a great influence of the type of substituents attached to the polymer backbone on the properties of the materials. The glass-transition temperatures of these polymers, for example, increased with an increasing rigidity of the substituents in the polymer (phenyl/methyl vs. nonyl/ethyl). ${ }^{[23]}$ Effects were even more pronounced in the case of the surface energies of spincoated films of these poly(2-oxazoline)s: ${ }^{[24]}$ If the polymers did not contain any block of poly(2-nonyl-2-oxazoline), the corresponding films had surface energies in the narrow range from 43 to $46 \mathrm{mN} \cdot \mathrm{m}^{-1}$; films of the polymers that contained (at least) one block of poly(2-nonyl-2-oxazoline), on the other hand, exhibited surface energies in the range from 22 to $24 \mathrm{mN} \cdot \mathrm{m}^{-1}$. Obviously, in terms of surface energies (and also in terms of contact angles, which had been measured before in order to calculate the surface energies), the investigated types of monomers could be arranged in two groups: methyl, ethyl, and phenyl versus nonyl.
In the present study, scanning force microscopy (SFM) tapping-mode investigations on spin-coated films of the diblock copoly(2-oxazoline)s were performed in order to study the surface structure of these films and to determine whether the surface morphologies (i.e., increased surface roughness, etc.) are correlated to intrinsic macroscopic properties of the polymers such as contact angles and, hence, also the surface energies of thin films.

\section{Experimental Part}

Microwave-Assisted Synthesis of Diblock Copoly(2oxazoline)s and Chain-Extended Homopoly(2-oxazoline)s

All polymerizations were performed under inert conditions in solutions of acetonitrile in a single-mode microwave reactor at $140^{\circ} \mathrm{C}$, utilizing methyl tosylate as initiator. The ratio of monomer to initiator was kept at 50; the initial concentration of the monomer, on the other hand, depended on the first monomer to be polymerized, and spanned a range from 2 to $4 \mathrm{M}$. Reaction times for the completion of the polymerization could be calculated from a precedent kinetic study; ${ }^{[20]}$ for further details on the synthesis, see ref. ${ }^{[23]}$

\section{Preparation of Polymer Films by Spin Coating}

Microscopy slides (Marienfeld, Germany) (cleaned according to a procedure described elsewhere $)^{[24]}$ were spin-coated at $1000 \mathrm{rpm}$ for $90 \mathrm{sec}$ using the spin coater WS-400/500 (Laurell Technologies Corp., PA).

\section{Atomic Force Microscopy}

Scanning force microscopy images were recorded with a Nanoscope IIIa Multimode SFM (Digital Instruments, Santa Barbara, CA, US) in tapping-mode operation with commercially available silicon SFM tips (NT-MDT, Russia) with a typical force constant of 5.5 to $11 \mathrm{~N} \cdot \mathrm{m}^{-1}$ (NSG11). For reproduction, images were flattened and no filter was applied.

\section{Results and Discussion}

Spin-coated films of 12 diblock copoly(2-oxazoline)s and the corresponding four homopoly(2-oxazoline)s, which 
Table 1. Overview over the 16-membered set of diblock copoly(2-oxazoline)s and chain-extended homopoly(2-oxazoline)s. In each cell, the first entry represents the compositions of the polymer (determined by combined GPC and ${ }^{1} \mathrm{H}$ NMR analysis). The second entry indicates the molecular weight (calculated for the targeted monomer ratio of 50:50). In line three, the PDI values are given (indicating the narrowness of the molecular weight distribution); the left (right) value was obtained from GPC measurements in chloroform (DMF).

Second block $\rightarrow$
First block $\downarrow$

Poly(2-methyl-2oxazoline), Me<smiles>CCC(=O)N(CCC(C)(C)C)C(C)(C)C</smiles>

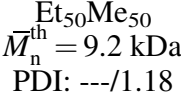

PDI: ---/1.18

$$
\begin{gathered}
\mathrm{Non}_{50} \mathrm{Et}_{46} \\
\bar{M}_{\mathrm{n}}^{\mathrm{th}}=14.8 \mathrm{kDa} \\
\text { PDI: } 1.64 /---
\end{gathered}
$$

$\mathrm{Et}_{50} \mathrm{Non}_{50}$
$\bar{M}_{\mathrm{n}}^{\mathrm{th}}=14.8 \mathrm{kDa}$

PDI: 1.15/---
$\mathrm{Et}_{50} \mathrm{Phe}_{52}$
$\bar{M}_{\mathrm{n}}^{\mathrm{th}}=12.3 \mathrm{kDa}$

PDI: 1.27/1.19

Poly(2-ethyl-2oxazoline), Et<smiles>CCCCCCCCCC(=O)N(CCC(C)(C)C)C(C)(C)C</smiles>
PDI: $(1.6)^{\mathrm{a})} /---$

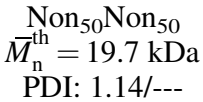
$\mathrm{Non}_{50} \mathrm{Phe}_{45}$
$\bar{M}_{\mathrm{n}}^{\mathrm{th}}=17.2 \mathrm{kDa}$ PDI: 1.24/---

Poly(2-nonyl-2oxazoline), Non<smiles>CC(C)(C)CCN(C(=O)c1ccccc1)C(C)(C)C</smiles>

$$
\begin{gathered}
\mathrm{Phe}_{50} \mathrm{Me}_{48} \\
\bar{M}_{\mathrm{n}}^{\mathrm{th}}=11.6 \mathrm{kDa}
\end{gathered}
$$

PDI: ---/1.18
$\mathrm{Phe}_{50} \mathrm{Et}_{46}$
$\bar{M}_{\mathrm{n}}^{\mathrm{th}}=12.3 \mathrm{kDa}$

PDI: $1.35 / 1.19$

$$
\begin{gathered}
\text { Phe }_{50} \text { Non }_{50} \\
\bar{M}_{\mathrm{n}}^{\text {th }}=17.2 \mathrm{kDa}
\end{gathered}
$$$$
\text { PDI: 1.28/-- }
$$

$$
\begin{gathered}
\text { Phe }_{50} \mathrm{Phe}_{50} \\
\bar{M}_{\mathrm{n}}^{\text {th }}=14.7 \mathrm{kDa}
\end{gathered}
$$

PDI: 1.27/1.16

Poly(2-phenyl-2oxazoline), Phe

a) In the case of $\mathrm{Me}_{50} \mathrm{Non}_{52}$ and $\mathrm{Non}_{50} \mathrm{Me}_{50}$, values for the PDI could be only estimated after a modification of the system based on chloroform. For details, see ref. ${ }^{[23]}$

were composed of 2-methyl-, 2-ethyl-, 2-nonyl-, and 2-phenyl-2-oxazoline (see Introduction), were investigated under hard-tapping SFM conditions ${ }^{[25]}$ to obtain information on structure/property relations. These measurement settings are suitable to obtain structural information on the morphologies of the spin-coated films. The results of these investigations are summarized in Figure 1. The morphologies of the four homopoly(2-oxazoline)s are shown along the diagonal of Figure 1(A) (starting in the top left corner). These films serve as reference samples for the film morphologies of the individual blocks and were moreover used to determine the surface energies of these homopoly(2-oxazoline)s. Thereby, two values for the surface energies could be determined. For the homopolymers of 2-methyl-, 2-ethyl-, and 2-phenyloxazoline, surface energies in the narrow range from 43 to $46 \mathrm{mN} \cdot \mathrm{m}^{-1}$ were measured. ${ }^{[24]} \mathrm{A}$ comparison of the surface morphology reveals a very similar surface structure of these homogeneous films, which show only very low surface roughness. In this figure, the $z-$ scale of the representation was adjusted to $5 \mathrm{~nm}$ for all films to allow a direct comparison. A more detailed analysis of these films is shown in Figure 2. The surface texture (A) plotted on a $z$-scale height of $2 \mathrm{~nm}$ and the corresponding phase images (B) reveal the homogeneous and similar surface structures for the three homopolymers. These compounds are amorphous polymers, as can be concluded from DSC measurements, which revealed one glass-transition temperature and no melting point. ${ }^{[23]}$ With this reference 
information, the films of the diblock copolymer composed of these three blocks were investigated. The sub-set of $3 \times 3$ films of diblock copolymers containing blocks of poly(2methyl-)-, poly(2-ethyl-)-, and poly(2-phenyl-2-oxazoline) is shown in the top left corner of Figure 1. Figure 2 represents a more detailed excerpt. It is evident that the film morphologies are very similar and that no additional surface textures of the films are visible in the corresponding phase [Figure 2(B)] and amplitude images (not shown). Besides the comparable surface structure of these films, it was found that the surface energies of all of these films are in the same range between 43 and $46 \mathrm{mN} \cdot \mathrm{m}^{-1},{ }^{[24]}$ just like those of the corresponding homopoly(2-oxazoline)s.

In contrast to these (overall) homogenous smooth films, the films of the diblock copoly(2-oxazoline)s that contain a block of poly(2-nonyl-2-oxazoline) exhibit significantly higher surface roughness $(z$-height $5-10 \mathrm{~nm}$ ). (The low quality of the film of $\mathrm{Non}_{50} \mathrm{Phe}_{45}$, which is observable by the agglomerates [Figure 1(A)], results from the standardized and not case-selectively optimized spin-coating conditions.) The increased surface roughness of these films is in good agreement with the film morphology of the homopoly(2-nonyl-2-oxazoline) film [bottom right corner of Figure 1(A)], which was used again as a reference sample to determine the properties of the homopolymer. Therefore, it can be concluded that the segment of poly(2-nonyl-2oxazoline) is responsible for the increased surface roughness of the spin-coated films. Moreover, it was found that the surface energies of the films of the diblock copolymers that contain a block of poly(2-nonyl-2-oxazoline) span a narrow range of surface energies from 22 to $24 \mathrm{mN} \cdot \mathrm{m}^{-1}$, which is similar to the surface energy of the homopoly(2nonyloxazoline), which was determined to be $22 \mathrm{mN}$. $\mathrm{m}^{-1} \cdot{ }^{[24]}$

This observation can be explained by the migration of the poly(2-nonyl-2-oxazoline) segments to the surface of the spin-coated films, like it was also described for block copolymers containing segments of poly(2-undecyl-2oxazoline) ${ }^{[26]}$ Hence, the similar surface energies of the films that contain a block of poly(2-nonyl-2-oxazoline) originate from the fact that these surfaces are (partially or completely) covered with the block of poly(2-nonyl-2oxazoline). The higher surface roughness of the poly(2nonyl-2-oxazoline) containing block copolymers most likely results from (partial) crystallization of the nonyl side-chains as it was recently demonstrated by the preparation of a series of linear 2-alkyl-2-oxazoline monomers and the corresponding polymers. ${ }^{[27]}$ The lower surface roughness of the $\mathrm{Et}_{50} \mathrm{Non}_{50}$ and $\mathrm{Non}_{50} \mathrm{Et}_{46}$ [Figure 1(A)] can be explained by the good compatibility of the poly(2-ethyl-2oxazoline) and poly(2-nonyl-2-oxazoline):: ${ }^{[28]}$ The poly(2-ethyl-2-oxazoline) segments will be mixed with the poly(2-nonyl-2-oxazoline) segments, and thus the crystallinity of the poly(2-nonyl-2-oxazoline) will be disturbed resulting in a lower roughness.

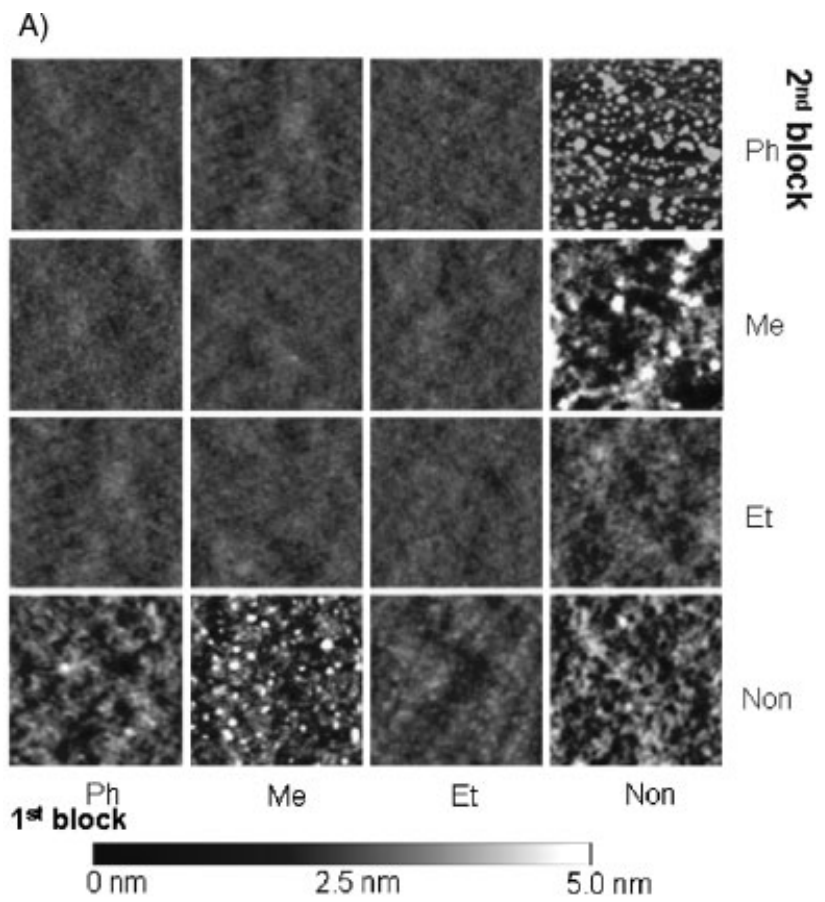

B)
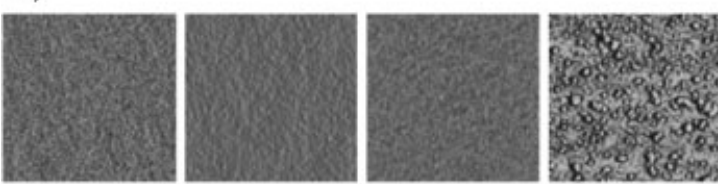

Ph 끙
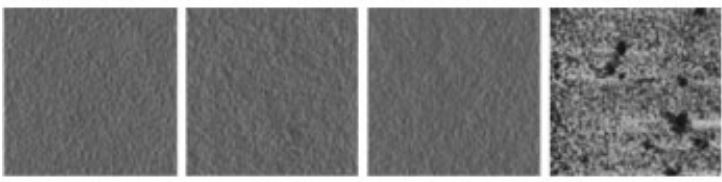

Me
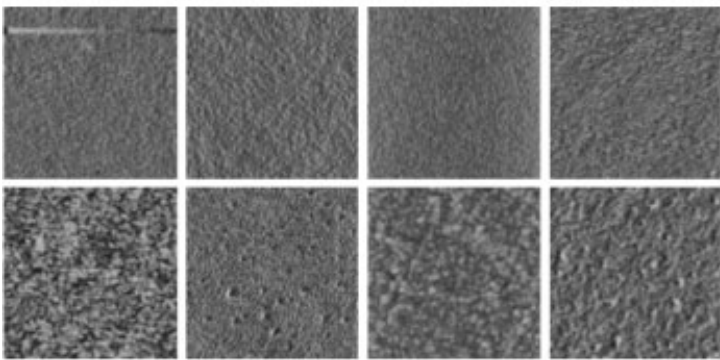

$\mathrm{Ph}$

$1^{\text {st }}$ block

Me

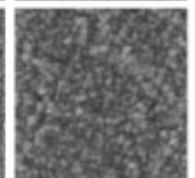

Et

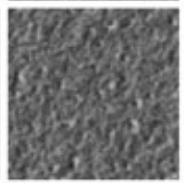

Non

$0^{\circ}$

$5^{\circ}$

$10^{\circ}$

Figure 1. AFM images $(1 \mu \mathrm{m} \times 1 \mu \mathrm{m})$ of spin-coated films of the library of 16 diblock copoly(2-oxazoline) on glass substrates. Me, Et, Non, Ph represent blocks of poly(2methyl-)-, poly(2-ethyl-)-, poly(2-nonyl-)-, and poly(2-phenyl2-oxazoline), respectively. (A) Topography images of the individual films recorded under hard tapping conditions. (B) Corresponding phase images of the films.

In addition to the surface morphologies, the surface textures of the spin-cast polymer films were examined in the phase images [Figure 1(B)]. Significant differences 
A)

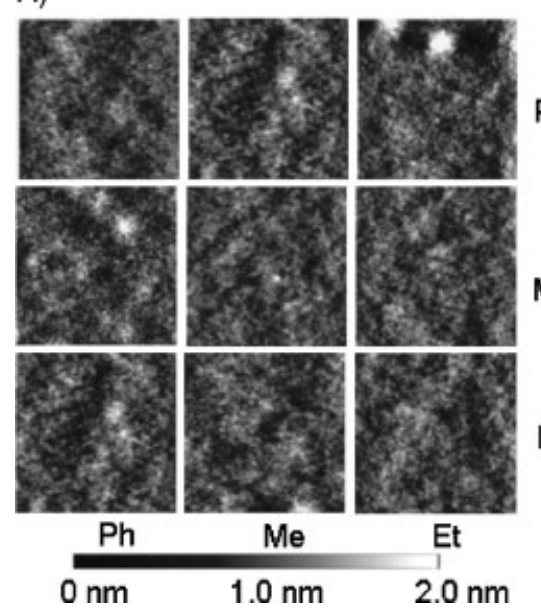

B)

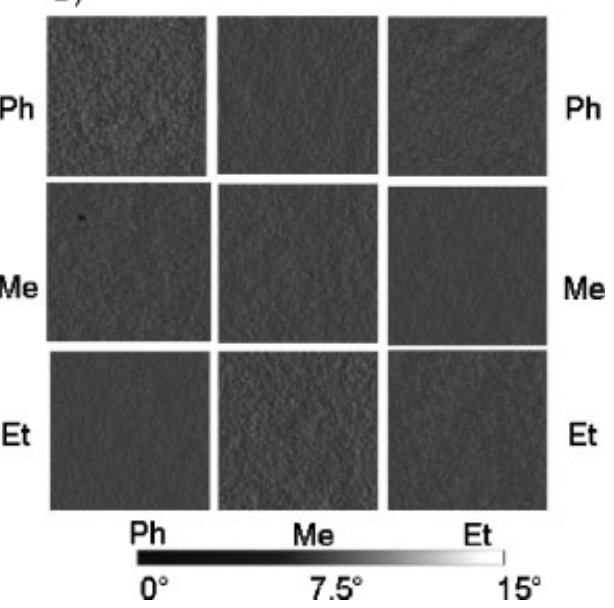

Figure 2. Topography (A) and phase images (B) (scan size: $1.5 \mu \mathrm{m} \times 1.5 \mu \mathrm{m}$ ) of the sublibrary consisting of $3 \times 3$ nonyl-free diblock copoly(2-oxazoline)s.

in the surfaces textures were found in the phase images of the poly(2-nonyl-2-oxazoline) containing copolymers. The films of the diblock copolymers $\mathrm{Me}_{50} \mathrm{Non}_{52}$ and $\mathrm{Non}_{50} \mathrm{Me}_{50}$, for example, revealed characteristic surface textures [Figure 1(B)]. This phenomenon is also observed, although to a minor degree, for the films of the diblock copolymers $\mathrm{Phe}_{50} \mathrm{Non}_{50}$ and $\mathrm{Non}_{50} \mathrm{Phe}_{45}$. This observation seems to contradict the initial assumption (based on surface energies) that the film surface is covered with chains of poly(2-nonyl-2-oxazoline) due to the migration of this component to the surface. Therefore, the different surface textures might originate from (at least partial) crystallization of the blocks of poly(2-nonyl-2-oxazoline) at the surface [Figure 1(B)]. Evidence for the crystallization tendency derives also from DSC investigations. ${ }^{[28]}$ Due to the increased hardness of these crystalline structures, tapping-mode SFM reveals the characteristic texture of the crystallization, especially in the phase images. The relatively mobile surface region will thereby support an enhanced rate of conformational transitions, which supports the crystallization of the blocks of poly(2-nonyl-2oxazoline) at the surface. ${ }^{[29]}$ However, from the current data it cannot be distinguished whether the observed surface textures result from phase-separated crystalline and noncrystalline poly(2-nonyl-2-oxazoline) blocks and/or from phase separation of the poly(2-nonyl-2-oxazoline) and parts of the other block, whereby the fraction of the second block at the surface should be sufficiently low not to influence the (macroscopic) surface energy. It should be emphasized that the formation of these surface textures is a phenomenon limited to the surface of these thin polymer films and not necessarily reflects the bulk properties of the films.

In the phase images [Figure 1(B)], it can be recognized that complementary copolymers do not reveal the same kind of crystallization behavior, despite the symmetric character of their blocks and the identical conditions during the preparation of the films, e.g., in the case of the diblock copolymers $\mathrm{Non}_{50} \mathrm{Me}_{50}$ and $\mathrm{Me}_{50} \mathrm{Non}_{52}$, which show the most pronounced surface textures. The height images of both systems reveal that the respective surface roughness is in the same order of magnitude [cp. Figure 1(A); Figure 3 represents a direct comparison of both films for easier comparison]; the surface texture (Figure 3) however appears to be very different. The film of the diblock copolymer $\mathrm{Me}_{50} \mathrm{Non}_{52}$ seems to exhibit a lamellar structure, whereas that of the diblock copolymer $\mathrm{Non}_{50} \mathrm{Me}_{50}$ shows a more cylindrical surface texture. Also for other pairs of diblock copolymers containing blocks of poly(2-nonyl-2-oxazoline), non-identical surface textures are observed. These differences in the surface patterns of complementary diblock copolymers that contain a block of poly(2-nonyl-2-oxazoline) most likely originate from chain transfer reactions that occurred during the synthesis of the diblock copoly(2-oxazoline)s that contain a block of poly(2-nonyl-2-oxazoline) as first block (for details, see ref. ${ }^{[23]}$ ). In these cases, namely $\mathrm{Non}_{50} \mathrm{Me}_{50}, \mathrm{Non}_{50} \mathrm{Et}_{46}$, and $\mathrm{Non}_{50} \mathrm{Phe}_{45}$, the final product contained a small fraction of homopoly(2-oxazoline) of the second monomer [poly(2methyl-2-oxazoline), poly(2-ethyl-2-oxazoline), or poly(2phenyl-2-oxazoline), respectively]. Since the overall polymer compositions are comparable, the presence of homopoly(2-oxazoline)s implies that the fraction of poly(2nonyl-2-oxazoline) that is actually incorporated in the block copolymers is higher in the block copolymers with poly(2-nonyl-2-oxazoline) as first block than in the block copolymers with poly(2-nonyl-2-oxazoline) as second block. The present homopolymers, which have a higher surface energy, will remain in the bulk and thus the effective block polymer compositions at the surface will be different for the complementary $\mathrm{AB}$ and $\mathrm{BA}$ block copolymers resulting in the observed different surface textures. 
A)

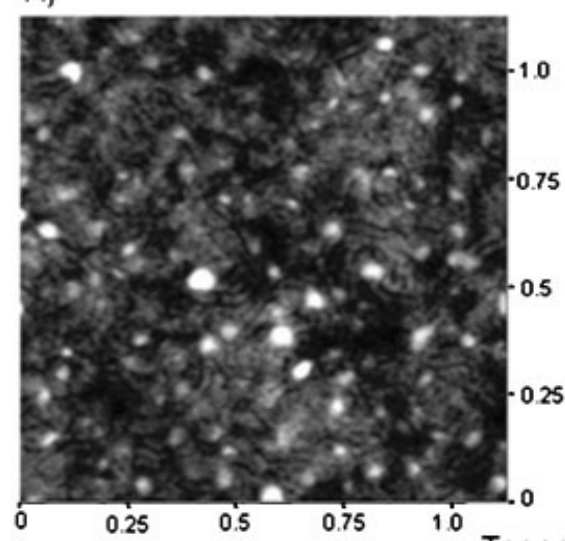

B)

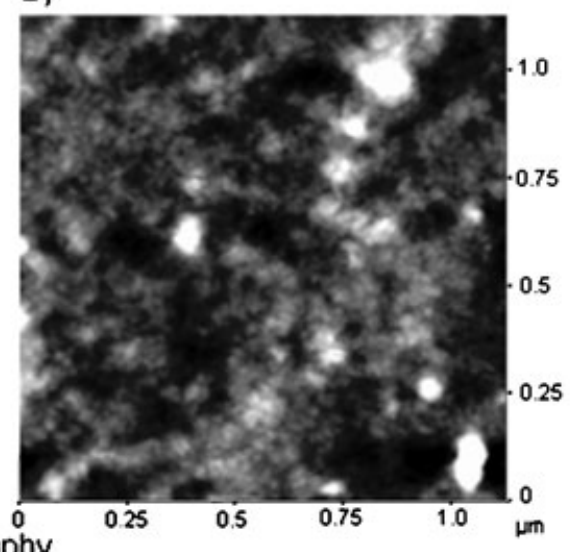

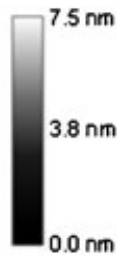

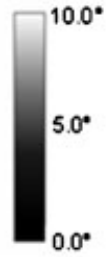

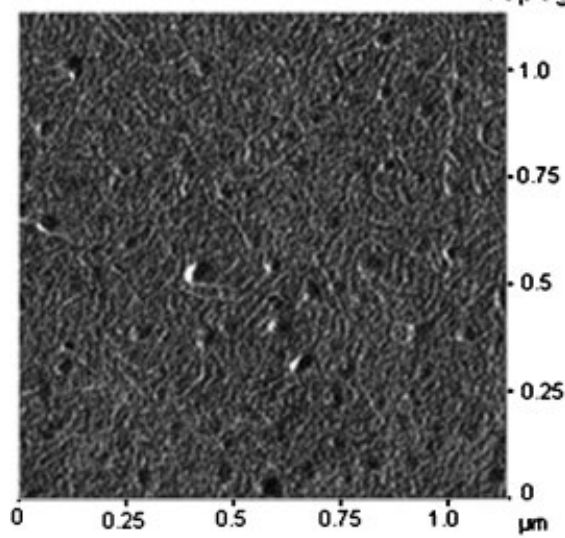

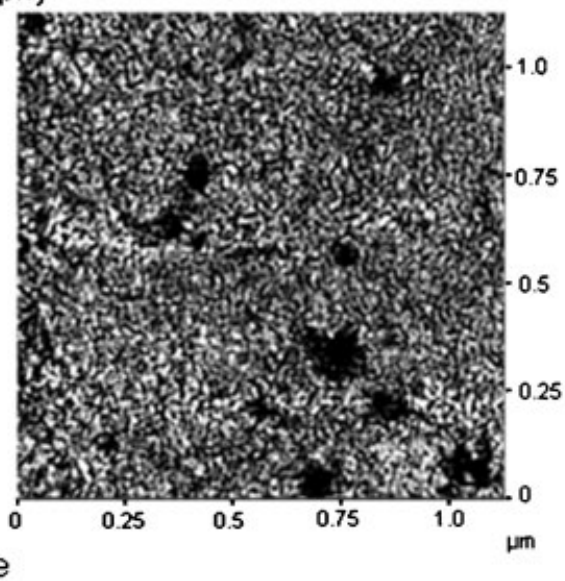

Phase

Figure 3. Topography (top) and phase images (bottom) of films of complementary diblock copoly(2oxazoline)s (scan size $1.13 \mu \mathrm{m} \times 1.13 \mu \mathrm{m}$ ). Even though the polymers are symmetric in their overall composition, it is observed that both films exhibit different surface textures probably due to different effective polymer compositions at the surface. (A) The film of $\mathrm{Me}_{50} \mathrm{Non}_{52}$ seems to exhibit a lamellar surface texture. (B) The film of $\mathrm{Non}_{50} \mathrm{Me}_{50}$ is characterized by a cylindrical surface texture.

\section{Conclusion}

Tapping-mode SFM investigations of films of diblock copoly(2-oxazoline)s, which were spin-coated in comparable processes on glass substrates, revealed a strong influence of the composition of the diblock copolymers on the morphology of the film. According to structural aspects, the surfaces of the films could be divided into two categories, depending on the presence or absence of blocks of poly(2nonyl-2-oxazoline) in the respective diblock copolymer. While the latter systems exhibited very smooth surface morphologies, it was observed that the diblock copolymers that contained blocks of poly(2-nonyl-2-oxazoline) exhibited rougher surface textures and showed additionally the tendency to (partial) crystallization. These observations are perfectly reflected by the findings from a previous determination of the surface energies. While the roughness of the surfaces only depended on the presence or absence of blocks of poly(2-nonyl-2-oxazoline) in the diblock copolymer, it was found that the textures of the surfaces were very sensitive towards small amounts of homopolymer impurities that could lead to different effective polymer compositions at the surface.

Acknowledgements: The authors would like to thank the Dutch Polymer Institute (DPI), the Nederlandse Wetenschappelijk Organisatie (NWO), and the Fonds der Chemischen Industrie for financial support as well as Henkel for providing 2-phenyl- and 2-nonyl-2-oxazoline.

[1] D. Delorme, Y. Ducharme, C. Brideau, C.-C. Chan, N. Chauret, S. Desmarais, D. Dube, J.-P. Falgueyret, R. Fortin, J. Guay, P. Hamel, T. R. Jones, C. Lepine, C. Li, M. McAuliffe, C. S. McFarlane, D. A. Nicoll-Griffith, D. Riendeau, J. A. Yergey, Y. Girard, J. Med. Chem. 1996, 39, 3951. 
[2] K. Aoi, M. Okada, Prog. Polym. Sci. 1996, 21, 151.

[3] D. A. Tomalia, D. P. Sheetz, J. Polym. Sci. 1966, 4, 2253.

[4] [4a] W. Seeliger, E. Aufderhaar, W. Diepers, R. Feinauer, R. Nehring, W. Thier, H. Hellmann, Angew. Chem. 1966, 78, 913; [4b] W. Seeliger, E. Aufderhaar, W. Diepers, R. Feinauer, R. Nehring, W. Thier, H. Hellmann, Angew. Chem. Int. Ed. Engl. 1966, 5, 875.

[5] T. Kagiya, S. Narisawa, T. Maeda, K. Fukui, Polym. Lett. 1966, 4, 441.

[6] A. Levy, M. Litt, J. Polym. Sci., Part A: Polym. Chem. 1968, $6,1883$.

[7] S. Kobayashi, H. Uyama, J. Polym. Sci., Part A: Polym. Chem. 2002, 40, 192.

[8] R. H. Jin, J. Mater. Chem. 2004, 14, 320.

[9] C.-H. Wang, G.-H. Hsiue, Biomacromolecules 2003, 4, 1487.

[10] Y. Chujo, K. Sada, T. Saegusa, Macromolecules 1993, 26, 6315.

[11] S. Kobayashi, T. Igarashi, Y. Moriuchi, T. Saegusa, Macromolecules 1986, 19, 535.

[12] D. Schönfelder, K. Fischer, M. Schmidt, O. Nuyken, R. Weberskirch, Macromolecules 2005, 38, 254.

[13] C. Kim, S. C. Lee, J. H. Shin, J.-S. Yoon, I. C. Kwon, S. Y. Jeong, Macromolecules 2000, 33, 7448.

[14] T. Tarvainen, T. Karjalainen, M. Malin, S. Pohjolainen, J. Tuominen, J. Seppala, K. Jarvinen, J. Controlled Release 2002, 81, 251 .

[15] C.-H. Wang, G.-H. Hsiue, J. Polym. Sci., Part A: Polym. Chem. 2002, 40, 1112.
[16] Y. Chujo, K. Sada, K. Matsumoto, T. Saegusa, Macromolecules 1990, 23, 1234.

[17] Y. Chujo, Y. Yoshifuji, K. Sada, T. Saegusa, Macromolecules 1989, 22, 1074

[18] F. Wiesbrock, R. Hoogenboom, C. H. Abeln, U. S. Schubert, Macromol. Rapid Commun. 2004, 25, 1895.

[19] R. Hoogenboom, F. Wiesbrock, M. A. M. Leenen, M. A. R. Meier, U. S. Schubert, J. Comb. Chem. 2005, 7, 10.

[20] F. Wiesbrock, R. Hoogenboom, M. A. M. Leenen, M. A. R. Meier, U. S. Schubert, Macromolecules 2005, 38, 5025.

[21] F. Wiesbrock, R. Hoogenboom, U. S. Schubert, Macromol. Rapid Commun. 2004, 25, 1739.

[22] R. Hoogenboom, M. Leenen, F. Wiesbrock, U. S. Schubert, Macromol. Rapid Commun. 2005, 26, 1773.

[23] F. Wiesbrock, R. Hoogenboom, M. Leenen, S. F. G. M. van Nispen, M. van der Loop, C. H. Abeln, A. M. J. van den Berg, U. S. Schubert, Macromolecules 2005, 38, 7957.

[24] S. Wijnans, B. J. de Gans, F. Wiesbrock, R. Hoogenboom, U. S. Schubert, Macromol. Rapid Commun. 2004, 25, 1958.

[25] S. N. Magonov, V. Elings, M.-H. Whangbo, Surf. Sci. 1997, 375, L385.

[26] G. Cai, M. H. Litt, J. Polym. Sci., Part A: Polym. Chem. 1989, $27,3603$.

[27] R. Hoogenboom, M. W. M. Fijten, H. M. L. Thijs, B. M. van Lankvelt, U.S. Schubert, Design. Monom. Polym. 2005, 8, 659.

[28] R. Hoogenboom, M. W. M. Fijten, R. M. Paulus, H. M. L. Thijs, S. Hoeppener, G. Kickelbick, U. S. Schubert, Polymer 2006, 47,75 .

[29] J. A. Forrest, J. Mattsson, Phys. Rev. E 2000, 61, R53. 